Does one Trust Judgement Fit All? Linking Theory and Empirics

\author{
Justin Fisher \\ Magna Carta Institute \\ Brunel University \\ Uxbridge, Middlesex UB8 3PH \\ United Kingdom \\ justin.fisher@brunel.ac.uk \\ Jennifer van Heerde \\ Department of Political Science \\ University College London \\ 29-30 Tavistock Sq \\ London WC1H 9QU \\ United Kingdom \\ j.heerde@ucl.ac.uk \\ Andrew Tucker \\ London Centre for Corporate Governance and Ethics \\ Birkbeck, University of London \\ Malet Street \\ London WC1E 7HX \\ United Kingdom \\ andrew.tucker@pol-soc.bbk.ac.uk
}




\title{
Does one Trust Judgement Fit All? Linking Theory and Empirics
}

\begin{abstract}
Few questions in political science have received more attention in recent times than the role of trust in democracy, democratic government, and political participation. In Britain this has become a particular concern as levels of democratic engagement in traditional politics have declined, exacerbated by media reports of politicians' untrustworthy behaviour. A common feature of previous empirical work on political trust is that trust is treated as a single theoretical concept. Scholars have assumed that trust operates in a similar fashion across different political institutions - that citizens' trust mechanisms are the same for trusting Parliament, the prime minister, or the European Union. As a consequence, the operationalisation of trust has generally been through a single measure. In this article we draw on recent research from political theory, where different forms of judgements whether to trust - strategic, moral and deliberative - have been conceptualized, to argue that trust judgements may vary in application and significance depending upon the institution under examination. Using specially designed datasets generated from YouGov's weekly omnibus and the British Election Study's Continuous Monitoring Panel, we operationalise these three forms of trust judgements to examine trust in two British institutions - political parties and politicians. We find, as hypothesised, that different forms of trust judgements are of differing significance depending upon the institution under consideration.
\end{abstract}




\section{Introduction}

Few questions in political science have received more attention in recent times than the role of trust in democracy, democratic government, and political participation. Within this literature, several key debates endure. First, whether the level of trust in democracy is rising or falling over time (Inglehart and Welzel 2005; Macedo 2005; Norris 1999; Skocpol 2003; Dalton 2006; Zukin et al. 2006; Ladd 1999; Lin 2001; Pattie, Seyd and Whiteley 2004); second, whether citizen trust is a prerequisite for good democratic government (Abramson and Finifter 1981; Citrin 1974; Citrin et al. 1975; Patterson, Ripley and Quinlan 1992; Dalton 2004; Hetherington 2005; Mackenzie and Labiner 2002; McDonald and Popkin 2001; Miller 1974; Nye et al. 1997; Pharr and Putnam 2000; Stokes 1962; Warren 1999); and third, whether trust should be conceptualised as a social construct, an institutional dilemma, or an economic by-product (Craig, 1993; Miller and Borrelli 1991; Owen and Dennis 2001; Duck 1997; Kramer and Tyler 1995; Seligman 1997; Sztompka 1999; Barber 1987; Hart 1978; Wright 1976).

Cutting across these debates is a vibrant literature concerned with the generation of trust in political institutions. Here, variation in levels of trust across different institutions has been attributed to the differences in individual level attributes, e.g. greater interest or knowledge of politics (Almond and Verba 1963; Dirks and Skarlicki 2004; Newton and Norris 2000); to attributes of the institutions themselves, e.g. the process legitimacy of courts (Grosskopf and Mondak 1998; Gibson and Caldeira 1995) or to broad socio-political trends in public opinion, e.g. business being more trusted to deal with climate change than national governments (Edelman 2008). Individual level attributes have been used to 
explain surprising empirical findings. For example, scholars of the U.S. Congress have found that while trust in Congress as an institution is at an all time low, many citizens claim to trust their own member (Bianco 1994; Parker and Parker 1993). A recent poll comparing trust in regulating the safety of pharmaceutical drugs, found that nearly half of respondents somewhat trust or very strongly trust the Food and Drug Administration (FDA), the regulatory agency responsible for safety in prescription drugs, whereas only $20 \%$ somewhat trust or very strongly trust Congress (Harris Interactive 2007). Although both institutions are deemed responsible for delivering safe food and drugs to the American public, respondents make use of differentiated judgements in determining which institution is more trustworthy.

Taking an overview of these various debates, we can observe that trust in the political sphere involves granting other political actors discretionary powers over the use of collective goods while recognizing that this judgement comes at some risk to oneself. More precisely, we can distinguish three components in the judgement whether to trust another political actor: (i) the perceived particular qualities of the trustee actor (or institution), (ii) the trusting characteristics of the truster, and (iii) the presence of mechanisms to protect the truster from betrayal by the trustee. Given the various potential interactions between these three components of the trust judgement, there is a strong $a$ priori case that various forms of trust judgements operate in the political sphere according to the type of political actor/institution to be trusted. An explicit assumption underlying this conceptualisation is that the trust judgement operates differently across different political institutions; in other words, citizens' judgements to trust operate differently in 
trusting Congress or Parliament, the president or prime minister, or for that matter, the European Union, NHS, or Federal Reserve. ${ }^{1}$

Despite the a priori case for the trust judgement as a multidimensional concept (Hibbing and Theiss-Morse 1995; Newton 1999; Tucker 2004, 2006, 2008), previous efforts to operationalise trust have tended to assume trust functions as a uni-dimensional concept in the political sphere (Hetherington 1998; Levi and Stoker 2000; Mishler and Rose 2001). ${ }^{2}$ Regardless of whether trust is employed as an independent or dependent variable, asking citizens - Do you trust in government? - or-How much trust do you have in government? - has generally been the shared standard, and we argue raises questions of the validity of such measures. If we accept the assumption that trust operates similarly across different political institutions, then previous research has been, at a minimum, face valid. However, there is good reason to argue that a trust judgement is not a unidimensional concept, and as a result, the operationalisation of trust in the political sphere in previous research fails to tap the full range of meanings of the concept. Consequently, empirical accounts of variation in trust across institutions may provide only a partial, and perhaps erroneous, explanation.

We aim to contribute to the literature on political trust in reconsidering the construct and content validity of political trust. In this article we articulate three forms of trust judgement-strategic, moral and deliberative-and test the general hypothesis that existing models of trust fail to capture the variation in which trust operates in the public sphere. We argue that trust judgements work differently across different institutions and test for evidence of three forms of trust judgement in two British institutions, political 
parties and politicians, and then test whether political trustworthiness is affected by political context. We do not make or test the claim that some citizens may have consistent preferences for one form of trust judgement over another; instead, the contribution here is simply to show that different forms of trust judgement may operate at different times, and that individuals may employ different forms of trust judgement for different events or situations.

\section{Theorizing Forms of Trust Judgements}

As noted in the previous section, the large literature on political trust indicates that the judgement whether to trust another political actor has three components: (i) the perceived particular qualities of the trustee actor (or institution), (ii) the trusting characteristics of the truster, and (iii) the presence of mechanisms to protect the truster from betrayal by the trustee. In this section, we do not aim to present a full typology of the trust concept as it appears in the political theory literature; rather we focus on those forms of trust judgement that have gained foremost theoretical support among researchers and have driven empirical studies to test their validity.

\section{Strategic Trust}

A leading strand in the literature focuses on the first component of the trust judgement as it concerns the perceived particular qualities of the trustee actor (or institution). The trust judgement is conceived around whether, either anticipating or evaluating cognitive understanding of limited information, to place oneself in a position of potential vulnerability by granting others discretionary power over one's interests (Elster 1979; Baier 
1986; Barber 1987; Dasgupta 1988; Gambetta 1988). Trust, on this reading, should be understood solely as the outcome of a rational judgement process. When an individual trusts another, it necessarily involves a judgement that the trust extended will not be abused, or at least that the consequences of that abuse are outweighed by the potential benefits of trusting cooperation. As Russell Hardin puts it: "you trust someone if you have adequate reason to believe it will be in that person's interests to be trustworthy in the relevant way at the relevant time. One's trust turns not on one's own interests but on the interests of the trusted. It is encapsulated in one's judgement of those interests" $(1993,505)$. Elsewhere Hardin argues that, to say that I trust you implies that I "have reason to expect you to act, for your own reasons, as my agent with respect to the relevant matter" $(1999,26$, italics original). Putting this form of trust in formal terms, trust exists for A when he delegates to B control over good C in which A has an interest. Using Hardin's terminology, A has good reason to trust B when A can know that his interests in good C are encapsulated in B's interests in good C, because in knowing this, A knows something about B's motivations (1993; 1999, 24-26). Therefore, B is trustworthy just to the extent that he attends to A's interests.

In this form, the trust judgement operates as a quid pro quo-in exchange for exposing oneself to potential harm, one gains the potential benefits of social cooperation. The decision to trust is essentially a strategic judgement on the trusted's interests. Strategic trust judgements are applicable to the types of relationships that occur in the political sphere, such as when one trusts professionals, authorities, or institutions. Because distance exposes the truster to more opportunities for his vulnerabilities to be exploited, assurance 
is usually sought on (i) the existence of convergent interests, (ii) that the trusted party has the relevant knowledge, skills, and capabilities over the good in question, and (iii) relevant past performance. Only then may trust may be extended with some degree of confidence. For example, doctors require professional accreditation in order to practice; authorities' past performance offers evidence of competence and control of free-riding (McAllister 1995; Scholz and Lubell 1998); and institutions' displays of administrative fairness help explain why citizens obey the law (Tyler and Huo 2002), pay their taxes (Levi 1997; Lieberman 2003) and perform military service (Tilly 2005).

In respect of our study, then, we develop four hypotheses to examine strategic trust judgements. First, we propose that an individual citizen will trust political parties whose policies are perceived to encapsulate that citizen's policy interests. According to strategic trust, an individual citizen has good reason to trust political parties when that citizen understands - on the basis of limited information - that his/her individual interests in a policy matter are encapsulated in those parties' interests in the policy area. That is, political parties are trustworthy in the eyes of an individual citizen to the extent that they attend (to the best understanding of the individual citizen) to that citizen's interests in a particular policy matter. On the basis of this encapsulated trust, citizens will continue to find parties trustworthy until citizens perceive their individual interests to no longer be served. This suggests the following hypothesis:

$\mathrm{H}_{1}$ : Citizens will find political parties trustworthy according to the extent to which the political parties' policies reflect the individual's interests in that policy matter (See questions 1 \& 2 in tables $1 \& 2$ ) 
Second, we differentiate the trust judgements in political parties from the trust judgement in politicians. It is widely noted in the literature that voters trust their local elected representative more than the legislature where that representative sits (Bianco 1994; Parker and Parker 1993), or the political parties to which they belong (Orren 1997; King 1997). It is less widely understood how trust operates between individual citizens and politicians as a class. According to the strategic version of trust, an individual may find a class of individuals trustworthy according to two criteria. First, trust is possible when an individual is assured of the existence of convergent interests between him/her and the class of individuals. Second, trust is possible when the class of individuals possesses relevant knowledge, skills, and capabilities over the good in question. In terms then of an individual citizen and politicians as a class, strategic type of trust will only be present when the citizen is assured of convergent interests with those politicians who have exemplified their knowledge of the policy matter in question. In a modern democracy, these two criteria of strategic trust can only occur when the citizen critically judges the actions and words of the subset of politicians experienced in the relevant policy matter. Given the cacophony of voices in a vibrant modern democracy, it is then incumbent upon those politicians with experience of a particular policy area to make their actions and opinions known through relevant media. ${ }^{3}$ Therefore, we hypothesize that citizens will only find trustworthy those politicians that clearly articulate their positions relevant to a particular policy matter so that voters can decide whether their interests are encapsulated in those positions.

$\mathrm{H}_{2}$ : Citizens will find politicians trustworthy according how closely politicians' stated interests reflect the individual's interests in a particular policy matter (See question 4 in tables 1 \& 2) 
Third, we need to understand the causal direction in the relationship between past performance and trust when a citizen makes the trust judgement. The literature here is richest in the context of the evaluation of New Public Management reforms of central government. This research suggests that citizens' trust is a consequence of the efficient and effective performance of government and public administration rather than a precondition of that performance (Yogoda and Yuval 2003; Nye, Zelikow and King 1997; Verba, Schlozman and Brady 1995; Kohut 1998). Variables investigated as significant to this causal relationship include: confidence in service delivery, demography, individuals vs. institutions, bureaucracy vs. frontline staff, proven independence of performance measurements, expectations of services, organizational type, possibility of dialogue between service provider and user, honesty and openness in the political sphere, and opposition politicians criticizing government administration to garner votes (Bouckaert 1995; Bitner 1990; Bouckaert and van de Walle 2003; Bok 1997; Berman 1997; Aberbach and Rockman 2000; Christensen and Laegreid 2006; Haque 1998). While this literature has tended to focus on public service efficiency and financial accountability of political institutions, its basic causal relationship of performance leading to trust offers insights into citizens' strategic trust of political parties and politicians. We propose that citizens will find political parties trustworthy on the basis of their delivery in office of policy promises made during the preceding election. Similarly, citizens will find politicians trustworthy according to the extent to which their performance in office matches their promises in opposition. We hypothesize: 
$\mathrm{H}_{3}$ : Citizens will find political parties trustworthy according to whether they deliver on their policy promises (See question 3 in tables 1 \& 2)

$\mathrm{H}_{4}$ : Citizens will find politicians trustworthy according to whether they deliver on their policy promises (See question 5 in tables $1 \& 2$ )

\section{Moral Trust}

In contrast with strategic trust's rationalist, calculating approach to a trust judgement, a second leading strand in the literature focuses on the trusting characteristics of the truster. This is a normative approach that focuses on the moral commitment to be trustworthy, where trust is a moral norm that individuals are socialized to follow (Becker 1996; Held 1968; Hertzberg 1988; Horsburgh 1960; Jones 1996; Mansbridge 1999). On this reading, the character of the truster is essential to believing that most other people can be trusted, regardless of previous experience of the actual trustworthiness of other actors. As Uslaner $(2002,2)$ argues, trust is not exclusively experiential, but comes from an optimistic worldview that presumes strangers are trustworthy: "Trust in other people is based upon a fundamental ethical assumption: that other people share your fundamental values. They don't necessarily agree with you political or religiously. But at some fundamental level, people accept the argument that they have common bonds that make cooperation vital. And these commons bonds rest upon assumptions about human nature. The world is a beneficent place composed of people who are well-intentioned (and thus trustworthy)". Putting this form of trust in formal terms, A trusts B (as well as C, D, etc.) based on A's belief in the moral good of trusting others. Therefore, B is trustworthy simply because A's norm is to trust B regardless of $\mathrm{B}^{\prime}$ s interests. 
There is significant empirical evidence that some form of moral trust operates in the political sphere, in the form of field studies (Ostrom 1998; Newton 2002), historical case studies (Rothstein 2000), experimental approaches (Sally 1995), survey research (Inglehart 1999; Torpe 2000; Uslaner 2002), and international comparative research (Svallfors 1997; Kumlin 2002; Rothstein and Steinmo 2002). However, the empirical data are less clear about moral trust in politicians and political parties. Drawing on the World Values Survey, Uslaner $(2002,226-37)$ argues that democracies have higher levels of moral trust than authoritarian states, that greater economic equality drives higher levels of moral trust, and that Protestant countries have higher moral trust than Muslim societies. In other words, despite the current debate around MPs' expenses, bankers' bonuses, and seemingly intractable tensions within a multicultural society, a broader view of the demographics of the UK suggests that citizens share common bonds that make cooperation vital. In this sense, citizens accept an ethical assumption that other people share their fundamental values. Following this argument, we offer a hypothesis to examine the general moral form of trust judgement as it relates to politicians.

H5: A citizen will trust politicians because they have been socialized to do so (See question 8 in tables 1 \& 2)

Uslaner also makes an important and productive distinction for the trust judgement of political institutions between a "generalized" and "particularized" moral trust. While generalized trusters find others trustworthy, particularized trusters only find trustworthy "people of our own kind or our close friends" $(1999,124)$, for example, family, similar ethnic or religious groups. Particularized trust is typically formed in contradistinction to others outside the group. Individuals build strong bonds based on reciprocity and trust 
within their own group ("us"), spurred on by group identification in contrast with other groups ("them"). Because these bonds grow stronger and more exclusive, cooperative action with others becomes less likely, thus further reducing the possibility for broad collective decision-making. Particularized trusters are unlikely to seek out others, do not feel responsible for others on a moral level, and seek to resolve disputes through confrontation. In contrast with generalized trusters, particularized trusters are pessimistic about life and, as such, have a tendency towards introversion and asocial prioritization of their own group's interests. They are not seen as cooperative and generally believe others to be uncooperative as well, perhaps justifying their own behaviour. However, particularized trusters are not social isolates. They do trust and work cooperatively with some people, just not all people. For example, particularized trust facilitates the civic engagement of many specialized interests groups, from grassroots community organizations to national advocacy groups (Skocpol 2003). They associate, but only within a close-knit network of people that share similar traits and interests, like political party affiliation. In other words, particularized trusters engage, but only with each other, and not cautiously within the broad political sphere. Following this argument, we offer two hypotheses that seek to separate the generalized from the particularized form of moral trust as it relates to trust judgements in political parties.

$\mathrm{H}_{6}$ : Citizens will trust a political party that is inclusive of different types of people with different interests because they can share in general common goals (See question 6 in tables $1 \& 2$ )

$\mathrm{H}_{7}$ : Citizens will trust a political party with whom they share a common identity (See question 7 in tables 1 \& 2) 


\section{Deliberative Trust}

A third strand in the literature focuses on the final component of the trust judgement - the presence of mechanisms to protect the truster from betrayal by the trustee. ${ }^{4}$ Trust is taken here as a facilitating mechanism for collective action occurs through deliberation, innovation and cooperation rather than through a strategic, rational judgement of the trustee's interests or a moral judgement about human nature (Mendelberg 2002; Bornstein and Rapoport 1988; Kerr and Kaufman-Gilliland 1994; Larmore 1994; Orbell et al. 1988). A form of 'deliberative trustworthiness' describes the process of judgement where an individual first decides whether other actors involved in the decision-making process are sufficiently trustworthy to merit accepting their future promises of collective action. Once this initial judgement on the conditions of engagement in the political sphere can and has been made, the individual can participate in the broadly-defined political process by acting on promises resulting from the trustworthy decision-making process.

Deliberative theorists have investigated how another's trustworthiness may be assessed in order to determine whether agreement may be reached through deliberation (Galston 1988; Benhabib 1989; Christiano 1996; Bohman 1996; Elster 1998; Young 1999). Generally, these theorists take 'trustworthiness' to mean an individual's cognitive judgement of another political actor's motivation based on the nature of his deliberative relationship with that actor such that future cooperation may be possible between them. Habermas (1984) has arguably done most to isolate the criteria of deliberative trustworthiness with his account of how societies develop "second order" consensus - the methods of voting, bargaining, and compromise whereby public opinion is molded by argument and congeals around one 
course of political action. Habermas makes a basic distinction between action framed by deliberation with others and action framed solely by one's own preferences. Communicative action, as Habermas presents it (1984), is oriented towards inter-subjective understanding, the coordination of actions through discussion, and the socialization of members of the community.

This type of action stands in opposition to strategic action (inherent in the strategic trust form) where social action is oriented to success in influencing the actions of other rational actors. Communicative action involves actors in "the cooperative negotiation of common definitions of the situation" in which they are interacting (Habermas 1985, 137) so that they can pursue their individual plans without harming other actors' interests. Communicative action gains its motivational force by a "telos of consent, inherent in language itself" (ibid, 157) that motivates individual deliberators to judge whether another participant is deliberating as an equal and striving for consensus, or is acting strategically and gaming the deliberative process for an advantageous outcome. By comparison, strategic action does not have the same restrictive criteria for success. It is simply the pursuit of one's own interests by accepting any reasonable promise on offer from any source. By accepting promises without engaging in the deliberative process, the citizen cannot cooperatively negotiate "common definitions of the situation" and so must accept a position of limited information, and the heightened risks of betrayal that entails. 
While there is much discussion in the literature on the practical potential of communicative action, there is agreement across the spectrum that the deliberative aspect of communicative action provides a motivation to seek criteria by which to judge the trustworthiness of other deliberators. For example, Mansbridge's (1983) analysis of town meeting and workplace democracy; Hunold and Young (1996) have developed deliberative criteria applicable to aspects of the planning process; Chambers (1996) has examined the language-rights politics of Quebec; and Fung (2004) has produced a useful theory of empowered participation in the urban setting.

Habermas sets out the cognitive criteria by which an individual may judge the trustworthiness of other deliberators, like politicians and political parties. At the level of the political institutions like political parties and politicians is the concept of institutionalized deliberative mechanisms. Here, the trustworthiness of an institution is located in the extent to which its institutional structures promote fair and equitable deliberation with citizens. These structures should be aimed at full, equal, informed, and un-coerced participation in the rule- and regulation-making process by individuals who are guaranteed the freedoms and opportunities necessary to achieve this end (Habermas 1996, 305-7). What gives legitimacy to the eventual outcomes of this deliberative process (i.e. public policy proposals) is that "the only regulations and ways of acting that can claim legitimacy are those to which all who are possibly affected could assent in rational discourse" $(1996,458)$. Legitimation in the execution of their public policy proposals - the end goal of political parties - therefore requires channels for regulating the deliberative process of political institutions like political parties, so that they are not overwhelmed by 
non-deliberative means. In the case of political parties, the most powerful non-deliberative actors are large party funders who achieve and exercise their power by channeling resources to support their favoured policies rather than by winning support through deliberation with the party's wider supporter base. The trust judgement in parties is therefore related to the perceived fairness and equitableness of a political party's deliberative mechanisms. This argument offers the following hypothesis:

$\mathrm{H}_{8}$ : Citizens trust political parties whose policies reflect the interests of a wide range of their supporters rather than the interests of a small number of their funders (See Question 9 in tables 1 \& 2)

Institutionalized deliberative mechanisms offer a means by which political parties may be challenged. While citizens may not agree with all a party's policy proposals, its institutionalized "challengeability" makes it worthy of being trusted by citizens. More broadly, national and local elections institutionalize the "challengeability" of political parties at regular and predictable intervals. This institutional framework means that a citizen's judgement of a party's trustworthiness does not rely (cf. $\mathrm{H}_{1}$ ) on whether his/her individual interests in a policy matter are encapsulated in that party's interests in the policy area. Rather, a political party's trustworthiness is based on the degree to which the party's institutional structures promote, and accept the result of, fair and equitable deliberation with citizens. According to this argument, we propose the following hypothesis:

$\mathrm{H}_{9}$ : Citizens trust political parties that participate fully in, and abide by the results of, democratic elections (See Question 10 in tables 1 \& 2) 
Institutionalized deliberative mechanisms employed by politicians - the ways in which politicians promote fair and equitable deliberation with citizens - range from weekly oneon-one 'surgeries' for constituents to open-door parliamentary scrutiny committees to nationally televised press conferences. Politicians can be judged trustworthy according to the extent they make themselves available for these forms of deliberative process. Contrary to the particularized form of moral trust where citizens only trust politicians with similar traits and interests to themselves, the presence of deliberative mechanisms allows citizens to find trustworthy politicians from across the broad political sphere. Following this argument, we hypothesize:

$\mathrm{H}_{10}$ : Citizens trust politicians to the extent politicians deliberate openly and generally, even if the same citizens disagree with the process outcome (See Question 11 in tables 1 \& 2)

At the level of decision-making that includes facilitators (e.g. politicians) of the political process, is the concept of trustworthiness as a "relief mechanism". Habermas recognizes that communication is not always language-based $(1987,185)$. In post-traditional societies, where communication increasingly takes place in plural sites beyond the confines of linguistic discourse, participants need some form of "relief mechanism" to help mitigate the real or perceived threats from the non-language-based communication in the political sphere. Habermas focuses on internalities like prestige and influence because they reach beyond the particular space and time of the present situation and are recognizable and dominant within the groups where they pertain. This means they can substitute for mutual understanding where language and verbal communication are not possible. 
Facilitators - particularly politicians but also journalists, political activists, policy experts have what Habermas calls interactive responsibility and proficiency over knowledge. Their facilitating power is based on the relative qualities of their contributions to the public discourse. Habermas $(1987,179)$ argues that "When a prestigious or influential person takes the initiative, he can count on receiving a certain 'advance' of trust or confidence, which may be paid out in a readiness for consensus and obedience that goes beyond any single situation". So the trustworthiness of a facilitator comes from his prestige and influence being accepted as a functional relief from the inherent uncertainty of the political sphere, so allowing citizens to commit to future collective actions.

Prestige is ascribed to the individual actor; influence to the flow of communication itself. They are mutually reinforcing and interdependent-it is seldom the case that one exists without the other. The source of prestige is personal attributes like technical proficiency in the political process (getting elected to Parliament) and intellectual achievement (understanding, and being able to manipulate, how the political process works) $(1987,181)$. The primary source of influence is a learnt knowledge of the traditions of the political process (understanding how to get selected as a parliamentary candidate and how to campaign for office, ibid). Following this argument, we hypothesize:

$\mathrm{H}_{11}$ : Citizens will trust politicians depending on whether they are perceived to be prestigious and influential (See Questions 12 \& 13 in Tables 1 \& 2)

In the next section we test these hypotheses for evidence of which types of trust are most pertinent across different institutions. 


\section{Data and Methodology}

The data for this study were generated from YouGov's weekly online British Omnibus survey (N=1,753; July 2007) and the British Election Study Continual Monitoring Panel ( $N=1,018$; March 2009). Using nationally representative samples, we asked two sets of questions on political trust. First, and drawing on arguments presented in the literature review, respondents were asked to estimate how much trust they had in parties and politicians using an 11-point scale. These questions replicate the standard trust questions asked in the 2005 British Election Study (BES) and are used for comparison and capture overall, but undifferentiated levels of trust. ${ }^{5}$ Second, to operationalise the strategic, moral and deliberative forms of trust judgements, and to test the eleven hypotheses we derived a series of statements and asked respondents the extent to which they agreed or disagreed with statements on political parties and politicians on a 5-point Likert scale.

The choice of politicians and political parties as institutions is a 'critical' test for our conceptualization of political trust. One the one hand, it could be reasonably argued that electors perceive parties and politicians as essentially the same institution and thus employ the same mechanisms in their calculus to trust. If this is the case, we should find no evidence of different trust mechanism at work. We, however, take the position that parties and politicians, while related, are not the same. ${ }^{6}$ Whereas other (political) institutions, (e.g. Bank of England, judiciary), may provide for a greater contrast vis-à-vis parties and politicians in testing for different forms of trust, it is precisely the case where we have similar but different institutions that provides the most robust test of our 
conceptualization. The analysis proceeds in two parts: first, we examine the relative importance of the different forms of political trust judgements, and second, we examine these judgements to gauge whether political trust is affected by political context--e.g. testing for a correlation between trust in parties and politicians and supporters of the three major parties in Britain, Labour, Conservatives, and Liberal Democrats.

Our claim that different forms of trust operate simultaneously in the political sphere rests on demonstrating that the operationalisation of these three forms is construct valid; or alternatively, that the three forms of trust are theoretically informed, operationalised and tested with robust indicators that show an acceptable degree of correlation (Carmines and Zeller 1979, 23). To operationalise strategic, moral and deliberative trust judgements we developed a series of 13 survey questions that aim to measure the underlying theoretical construct for both political parties and politicians. Responses for the 2007 and 2009 data are detailed in Tables 1 and 2 respectively. The next section provides a general outline of our approach in operationalizing the three forms of trust.

Strategic trust: Questions 1-5 measure the extent to which respondents' feel, on balance, parties' policies encapsulate their policy interests and the extent to which politicians generally (rather than one's own elected representative) succeed in attending to the respondents' particular interests, as well as recognising that respondents' individual interests may be bound up in more general values and collective identities that play out in national debates, like immigration or gender issues. In other words, these questions reflect Hardin's argument that the judgement to trust is based on a rational understanding of the 
other actor's interests. The individual calculus of trust resembles this line of thinking: to the extent that a political party and/or politician's policies encapsulate my own interests I find them trustworthy to get on with the activities of governance; when parties and politicians no longer represent my interests, I no longer judge them trustworthy to govern. Of course, this rationalist calculus is made easier for citizens when knowledge of relevant past performance is available. Questions 3 and 5 tap into the extent to which the judgement to trust is a backward-looking assessment of the performance of previous promises.

Moral trust: Question 8 measures the extent to which individuals find politicians trustworthy regardless of previous experience. Perhaps surprisingly in light of the welldocumented lack of trust in the political system, we hypothesize that individuals will trust politicians depending on the individuals' socialisation to trust. Second, and following Uslaner, moral trust taps the extent to which individuals find parties trustworthy on the basis of a generalized trust (Q6) or a particularized trust (Q7). Here we aim to separate out the impetus of the individual trust calculus: is it based on judging whether the party to be trusted shares similar traits and interests with the citizen, or whether the party should be trusted according to the citizen's socialization to trust?

Deliberative trust: Questions 9-13 measure deliberative trust by tapping citizens' perceived access to the political process. In a deliberative political sphere, individuals recognise that the diversity of political interests means increased competition and participation in the political sphere for preferred policy outcomes. With an extended sphere, individuals cannot expect to 'win' every time and thus adopt a rationalist attitude toward outcomes: so 
long as political debate is open and procedurally legitimate, individuals can accept 'losing' on electoral or policy outcomes. We now examine the empirical evidence for our hypotheses.

\section{Results and Discussion}

Our first task is to demonstrate why existing empirical measures of trust are not sufficient in discriminating between trust forms operating in different political institutions. We show this by simply correlating overall levels of trust in parties and politicians (measured on the standard 11-point scale). The correlation is remarkably high $(\mathrm{r}=0.914, \mathrm{p}<.01)$ and suggests two possible interpretations. The first interpretation is that the underlying forms of trust employed by citizens for parties and politicians are indifferent, and any decision to trust involves the same underlying mechanism(s). This interpretation represents the approach taken by extant work on trust; essentially that of a single theoretical conceptualisation of trust operationalised and measured by the traditional 11-point scale survey question asking, 'How much trust do you have in government?' A second possibility however, is that the correlation conceals as much as it reveals. By using a single theoretical approach to measure trust, we are unable to determine whether there are differences in what generates trust in parties and politicians, or indeed any other institution. The high degree of correlation between levels of trust in two separate institutions suggests that there could be a potential failure to discriminate between forms of underlying trust and therefore creates a spurious degree of correlation in trust in different institutions. Thus, the aim of this article is to test whether there is any empirical evidence to support theoretically distinct forms of trust. 
What evidence then, do we find for our hypotheses regarding different forms of trust? Tables 1 and 2 details responses to individual questions in both surveys. Generally speaking, the net scores (agree minus disagree) are similar for both the 2007 and 2009 surveys. Notable differences between the results of the two surveys are highlighted in the discussion.

In respect of $H_{1}$ (see questions $1 \& 2$ ), there is suggestive evidence that parties serve political interests reasonably well. In the 2007 survey, nearly two-thirds of respondents indicate that they can usually find a party to vote for that reflects some of their views, and disagreement with this statement is relatively modest (especially compared with the other questions in this survey). In the 2009 survey, nearly three quarters of respondents take this view. Thus, citizens develop strategic trust in political parties if those parties offer positions policies that are of concern to the citizen, or if the winning party reflects some of their concerns - in both surveys, a plurality indicate that whoever wins an election, at least some of the respondents' views will be reflected. In respect of $\mathrm{H}_{2}$ (see question 4), we see that politicians are perceived, on balance, to be considering issues that matter to respondents - a clear majority in both surveys take this view. In respect of performance, however $\left(\mathrm{H}_{3}\right.$ and $\mathrm{H}_{4}$ - see questions 3 and 5), there is clear pattern suggesting that neither parties nor politicians are perceived to deliver on their promises, and therefore are afforded less strategic trust. Respondents clearly indicate that they do not feel that parties or politicians deliver on past promises and the results are remarkably similar over both surveys (see questions 3 and 5). 
In terms of moral trust, there are mixed results for parties and politicians. On the one hand, the perceived utility of parties and politicians to deliver collective goals, and therefore a form of moral trust is demonstrated. Relatively slim pluralities in both surveys support the idea of political parties as a means of achieving common goals supported by citizens of different backgrounds $\left(\mathrm{H}_{6}\right.$ - see question 6). For politicians, however, only a small proportion sees politicians as sharing the same goals and values $\left(\mathrm{H}_{5}\right.$ - see question 8$)$. In addition, less than $20 \%$ see party activists as being similar to them $\left(\mathrm{H}_{7}-\right.$ see question 7$)$. In each case, the results of both surveys are very similar.

[Insert tables 1 and 2 here]

In respect of deliberative trust, there would appear to be support for process by parties and politicians. First, there is clear support in both surveys for the notion of competitive elections over partisan interest $\left(\mathrm{H}_{9}\right.$ - see question 10). Citizens develop deliberative trust towards parties when the consequences of election outcomes are clear, even if these consequences may not chime with the citizen's own interests. Equally, there is a preference for process over outcome in respect of decisions taken by politicians $\left(\mathrm{H}_{10}-\right.$ see question 11). In both surveys, a slim plurality favours full discussion over the outcome, which may or may not serve the respondent's interests. Second, while politicians generate strategic trust by broadly reflecting respondents' concerns, their discussions mediated through Parliament were not considered in positive light in 2007. By 2009, however, a plurality felt that politicians were discussing the issues of most importance to the country 
$\left(\mathrm{H}_{11}\right.$ - see question 12$)$. In addition, nearly two- thirds in both surveys recognize the utility of politicians to consider complex issues on behalf of citizens $\left(\mathrm{H}_{11}\right.$ - see question 13$)$.

Third, parties lack deliberative trust through a lack of confidence in parties' integrity in terms of favouring financial supporters $\left(\mathrm{H}_{8}-\right.$ see question 9). However, it should be pointed out that this finding may have been exaggerated by the context of the 2007 survey. At the time, the 'loans for peerages' episode was still lingering on, and despite no charges being brought, press comment on the episode was largely negative. As Kleinnijenhuis et al. $(2006,98)$ show, 'malaise news' tends to lead to distrust in party leaders. The 2009 survey, while still delivering a negative net score, suggests that the events of 2006 and 2007 served to depress the level of this deliberative trust judgement.

Our next step is to evaluate the extent to which these forms of trust are themselves related across institutions. In other words, although we are seeking to measure different types of trust in different institutions, the forms of trust should still themselves be related, regardless of the institution under investigation. We examine this by creating scales of strategic, moral and deliberative trust judgements using the items for both parties and politicians. Using Cronbach's Alpha, we can see that reliability between the items is good (the scores are $.815, .741$ and .689 for strategic, moral and deliberative trust respectively). These results suggest that our forms of trust are robust because despite different questions being asked about different institutions, the alpha scores indicate that the items hang together reliably. 
We test our principal hypothesis, that different forms of trust will be more or less evident depending upon the institution in which trust is placed, by regressing measures of the various forms of trust against the overall level of trust in the relevant institution (parties or politicians) using the standard 11-point scale. Despite our criticisms of the single theoretical approach which informs this measurement, its use as a dependent variable is justified because it should capture all the myriad forms of trust in that institution. Thus, while the use of the 11-point scale cannot differentiate between the forms of trust detailed in this article and their relative importance to differing institutions, the unidimensional scale should capture an overall level of trust.

In order to test our hypothesis, it is necessary to be able to evaluate the relative impact of different forms of trust. All of our different trust judgements are measured on the same five-point scale. We can therefore directly compare the $b$ coefficients for each form of trust judgement within each regression. In each model, the dependent variable is overall level of trust in the relevant institution. The independent variables are measurements of various forms of trust judgement in that institution. In addition, we add three demographic control variables available in both datasets: social class, sex and age. Pattie et al. $(2004,62)$ suggest that all three of these have a bearing on trust in politicians. Class and sex are coded as dummy variables such that social groups A, B, and C1 are coded as 1, and C2, D and E as $0 ; 7$ and men are coded 1 and women as 0 . For age, previous studies have suggested a curvilinear relationship with trust in government (Curtice and Bromley 2002, 146) and politicians (Pattie et al. 2004, 62). As is common practice, we use age-squared alongside age as control variables. Finally, given the characteristics of the dependent variable, the 
regressions were run in two forms: OLS using the stepwise method and ordered logit. The results were virtually identical, and as a consequence, we report the results from the OLS regressions for ease of interpretation.

Tables 3 and 4 illustrate the results of the relevant regression analyses. All three forms of trust judgement contribute positively to overall levels of trust in parties (table 3), while the control variables have no statistically significant impact. In both 2007 and 2009, strategic trust captured through an evaluation of whether parties do what they say they will do has the strongest effect on generating overall levels of trust. Moreover, the standard errors of each coefficient indicate that the differences between the coefficients for this item and other independent variables are themselves statistically significant. In the 2007 dataset, all three forms of strategic trust have a positive impact on trust. In addition, deliberative trust (measured through an assessment of whom parties represent - supporters or funders) and moral trust (measured through an assessment of party members being similar to respondents) also contribute positively, though moral trust has least impact overall. In the 2009 study, we again see that forms of strategic trust are dominant, both being statistically significant from other positive judgements (the same deliberative and moral ones as in 2007). Interestingly, the second deliberative judgement in parties, which focuses on the electoral process, has a negative impact on overall trust in parties.

If we compare these results with those for politicians (table 4), there are both similarities and differences. As for parties, all forms of trust contribute positively to overall levels of trust in politicians in 2007. And strategic trust, measured by evaluations of whether 
politicians keep their promises has the strongest impact on overall trust - more than double that the next strongest judgement, moral trust. This moral judgement is statistically significant in terms of impact compared with a measurement of deliberative trust (measuring the degree to which politicians discuss the most important issues) and a further example of strategic trust. The results in 2009 are similar with the strategic and moral judgements that are most significant in 2007, again being reflected and in the same order. As with parties, none of the control variables reach traditional levels of statistical significance.

Overall, the results for parties and politicians both reveal that the generation of trust is a function of all three forms of judgement, but to varying degrees. For both parties and politicians, most trust is generated through a form of strategic trust - keeping promises. For parties, however, moral judgements are generally less important. Here, we see some difference compared with politicians, where moral judgements are significantly more important than deliberative judgements. By way of contrast, deliberative judgements are much more significant for generating trust in parties. In sum, then, our broad hypothesis is offered some support by the data. Despite the institutions of parties and politicians being ostensibly similar, there are notable differences in the relevance of different trust judgements. While strategic trust (measured by perceptions of parties and politicians fulfilling their promises) is most significant in generating overall levels of trust for both, moral trust judgements are much more significant for politicians. Equally, deliberative trust judgements matter more in the case of parties.

[Insert tables 3 and 4 here] 
Given that our broad hypothesis is offered some support by the data, it is now worth examining whether political context matters at all. Curtice and Bromley (2002, 144-148) show that temporal context is a factor in levels of trust and well as whether one is a supporter of the incumbent or opposition parties. For example, in 1996, Conservative supporters had higher levels of trust in government to put the nation's interests first, but following the 1997 election, higher levels were found amongst Labour supporters -an observation that was repeated in 2001. ${ }^{8}$ Similarly, Pattie et al. $(2004,252-4)$ found that trust in elected politicians was highest amongst Labour supporters (and indeed rose between 2000 and 2001 following Labour's second landslide victory). Such patterns are repeated elsewhere. Bélanger and Nadeau $(2005,125)$ note higher levels of trust amongst incumbent supporters in Canada, while Dalton and Weldon $(2005,941)$ show in a thirteen country study that supporters of opposition parties are more likely to be distrustful of parties. And, as Banducci and Karp (2003) show, 'losers' in consensual systems tend to be less dissatisfied than losers in majoritarian ones. Given that Britain uses a first past the post system at Westminster level, we may therefore expect to see different patterns of trust emerging from supporters of different parties, depending upon electoral success or failure. Broadly speaking, if there is variation, we might expect 'losers' to have lower levels of strategic trust, since as losers, their interests may be encapsulated to a lesser degree than winners. Equally, other forms of strategic trust measuring perceptions of delivery by parties and politicians may vary by partisanship - winners may have more of this type of trust. In terms of deliberative trust, 'winners' and 'losers' may also differ on questions of process - 'winners' may well be more outcome focussed than 'losers'. 
We test these hypotheses in tables 5 and 6, confining our analysis to supporters of the three principal parties. Table 5 examines trust in parties, and again uses the overall level of trust in parties as the dependent variable and includes the three demographic control variables of class, sex and age. It reveals firstly, that forms of strategic trust are significant for supporters of all three parties. That said, whereas all three strategic trust judgements are significant for Liberal Democrat supporters in both 2007 and 2009, only some are relevant for Conservative and Labour supporters. However, there are some differences between supporters of the different parties. First, while for Conservative and Labour supporters, forms of both moral and deliberative trust are also relevant; no form of moral trust is significant for Liberal Democrats. Second, in 2009, both Labour and Liberal Democrat supporters display less concern about the process of how elections take place than the outcome. This is possibly to be expected in the case of Labour supporters, since their party is in power. More surprising is the stance of Liberal Democrats. That said, by 2009, one of the forms of strategic trust judgements (that any winning party will reflect some of a respondent's view) is actually negatively signed amongst Liberal Democrats. Both of these findings may have been related to the likely prospect of a future Conservative government, with polls at the time (March 2009) showing a significant Conservative lead. Our control variable of social class is also statistically significant for Labour supporters in $2007-$ middle class Labour supporters are more likely to have trust in parties than working-class ones. 
These findings partially support our hypotheses. As predicted, the Conservatives only generate limited levels of strategic trust, while Labour and Liberal Democrat supporters are more consistently likely to generate trust through finding a party that reflects their views. The possible explanation for Liberal Democrat supporters being similar in this respect to those of Labour is the ideological proximity of Labour and the Liberal Democrats (at least up to the 2005 general election) (Bara 2006), which would be more likely to generate a greater range of strategic trust judgements than in the case of the Conservatives. Indeed, this suggestion is supported by the earlier finding that Labour and Liberal Democrat supporters developed less support for the electoral process rather than the outcome as the likelihood of a Conservative government grew.

For trust in politicians (table 6), there is again some variation across parties. For all three, strategic trust in the form of politicians keeping their promises has a very strong impact consistently strongest in both years for Conservative and Labour supporters and in 2007 for Liberal Democrats. However, while Labour supporters generate moral trust in each year, Conservatives only do so in 2007 and Liberal Democrats in 2009. Similarly, deliberative trust is not consistently generated by any party supporters, either in form or over time. Intriguingly, for both Labour and the Conservatives, social class has a statistically significant impact in 2007, though again, in a counter-intuitive way. Higher levels of trust in politicians are found in working-class Conservative supporters and middle-class supporters of Labour. Amongst Liberal Democrat supporters, women are more likely to trust politicians in 2007

[Insert tables 5 and 6 here] 
On the face of it, these results could be seen as puzzling given the patterns we find with parties. However, they are less puzzling if we acknowledge that forms of trust may vary by institution. Despite the similarity between parties and politicians, further differences emerge between the two in terms on trust judgement when we control for party support.

\section{Conclusion}

In this article, we aim to move away from previous research on trust in arguing that different forms of political trust operate simultaneously in the political sphere. The article highlights a clear example where theorists and empiricists have ignored the work of one another, and addresses a productive lacuna in previous work. Drawing on two unique datasets from 2007 and 2009, we identify and test three forms of trust judgements strategic, moral and deliberative-and find evidence of variation in types of trust for political parties and politicians. We present two key findings using data from Britain, first that the importance of different types of trust varies according to political institution and second, that this variation is furthered amplified when controlling for party preference.

While this article shows support for the three forms of trust judgement, the need for additional work across different and non-traditional political institutions is clear. As stakeholders in democratic institutions, citizens engage with a disparate number of public institutions, regulatory bodies, local authorities, third sector organizations, and the media. Each type of institutional setting and configuration has potentially different combinations of trust appropriate to it. In order to maximize an institution's specific levels of trust, its 
management and employees may be forced to work in unfamiliar and uncomfortable ways. For example, regulatory bodies may need to learn how to foster trustworthiness with a broad set of stakeholders (rather than industry insiders) in order to drive deliberative trust. Similarly, third sector organizations may need to reach beyond the norms and values they share with their supporters - norms and values that form the basis of their particularized moral trust model-in order to deliver services to their users who may respond instead to a deliberative trust model based on involvement in service provision planning.

As we move away from more traditional political institutions to global governance, we ought to investigate why recent survey data suggests large corporations are more trusted by citizens than government institutions (Edelman 2008). There is prima facie evidence that corporations tailor their stakeholder relations strategies around the forms of trust most appropriate to their audiences. Of course, many businesses seek to encapsulate the financial interests of the customers/shareholders in their own interests. More pertinently, UK supermarkets seek to build particularized moral trust with their customers by supporting IT investment in community schools-there is a shared norm in promoting local children's education. More broadly, major news media companies have built online discussion forums where the general public can deliberatively interact with journalists this builds trustworthiness in the company's brand and promise-acceptance of content by the general public. There are unexplored implications here for politicians and political parties across Europe: for public-private partnerships running health, education and housing services, for the respective authority given to corporations and regulators in 
tackling climate change, and even to help explain the rise of entrepreneurs as successful anti-politicians in Italy, Malaysia, Thailand, and Russia.

Knowing how and under what conditions citizens trust political institutions may help to shed light on one of the more enduring debates on political trust, that is, whether citizen trust is a prerequisite for good democratic government, and what, if anything, governments can do to boost levels of trust. Our analysis suggests politicians and parties should recognize which citizens are likely to trust them and according to what trust type that trust may be granted. To this end, politicians and parties may be more electorally successful if they stop trying to be trusted by all citizens and recognize how their promises, processes and personalities will appeal (or not) to subsections of the electorate according to the three forms of trust we outline in this article. Our results suggest that parties and politicians should be careful in what they promise to electors, because it is precisely overpromising and subsequently under-delivering that limits or damages trust. 


\section{References}

Aberbach, J. and Rockman, B. (2000) In the Web of Politics. Three Decades of the U.S. Federal Executive (Washington, DC.: The Brookings Institution Press).

Abramson, P. and Finifter, A. (1981) 'On the meaning of political trust: New evidence from items introduced in 1978', American Journal of Political Science, 25:2, 297-307.

Almond, G. and Verba, S. (1963) The Civic Culture: Political Attitudes and Democracy in Five Nations (Princeton: Princeton University Press).

Baier, A. (1986) 'Trust and antitrust', Ethics, 96:2, 231-260.

Banducci, S. and Karp, J. (2003) 'How elections change the way citizens view the political system: Campaigns, media effects and electoral outcomes in comparative perspective', British Journal of Political Science, 33, 443-467.

Bara, J. (2006) 'The 2005 manifestos: A sense of déjà vu?', Journal of Elections, Public Opinion and Parties, 16:3, 265-81.

Barber, B. (1987) The Logic and Limits of Trust (New Jersey: Rutgers University Press).

Barber, B. (1984) Strong Democracy: Participatory Politics for a New Age (Berkeley: University of California Press).

Becker, L. (1996) 'Trust as noncognitive security about motives', Ethics, 107: (October), 4361.

Bélanger, É. and Nadeau, R. (2005) 'Political trust and the vote in multiparty elections: The Canadian case', European Journal of Political Research, 44, 121-46.

Benhabib, S. (1989) 'Liberal dialogue versus a critical theory of discursive legitimation', in N. Rosenblum (ed), Liberalism and the Moral Life (Cambridge, Mass.: Harvard University Press), 143-56.

Berman, Evan M. (1997) 'Dealing with cynical citizens', Public Administration Review, 57:2, 105-112.

Bianco, W. (1994) Trust: Representatives and Constituents (Ann Arbor: University of Michigan Press).

Bitner, M. (1990) 'Evaluating service encounters: The effects of physical surroundings and employee responses', Journal of Marketing, 54:2, 69-82. 
Bohman, J. (1996) Public Deliberation: Pluralism, Complexity, and Democracy (Cambridge, MA: MIT Press).

Bok, D. (1997) 'Measuring the performance of government', in J. Nye, P. Zelikow, and D. King, (eds), Why People Don't Trust Government (Cambridge, Mass.: Harvard University Press: 1997), 55-76.

Bornstein, G. and Rapoport, A. (1988) 'Intergroup competition for the provision of steplevel public goods: Effects of preplay communication', European Journal of Social Psychology, 18, 125-144.

Bouckaert, G. (1995) 'Remodeling quality and quantity in management context', in A. Halachmi and G. Bouckaert (eds), Public Productivity through Quality and Strategic Management (IOS Press), 21-38.

Bouckaert, G. and Van de Walle S. (2003) 'Comparing measures of citizen trust and user satisfaction as indicators of 'good governance': Difficulties in linking trust and satisfaction indicators' in International Review of Administrative Sciences, 69:3, 329-344.

British Election Survey (BES). 2005. Available online at: http://www.essex.ac.uk/bes/ (accessed 04 February 2008).

Burns, N. and Kinder, D. (2000) Social Trust and Democratic Politics. Ann Arbor, Michigan: National Election Studies.

Carmines, E. and Zeller, R.A. (1979) Reliability and Validity Assessment (London: Sage).

Christiano, T. (1996) The Rule of the Many: Fundamental Issues in Democratic Theory (Boulder, CO: Westview Press).

Christensen, T. and Laegreid, P. (2006). Autonomy And Regulation Coping with Agencies in the Modern State (London: Edward Elgar).

Citrin, J. (1974) 'The political relevance of trust in government', American Political Science Review, 68:3, 973-988.

Citrin, J., McClosky, H., Shanks, J. and Sniderman, P. (1975) ‘Personal and political sources of alienation', British Journal of Political Science, 5, 1-31.

Craig, S. (1993) Broken Contracts: Changing Relationships between Americans and their Government (Boulder, CO: Westview Press).

Curtice, J. and Bromley, C. (2002) 'Where have all the voters gone?', in A. Park, J. Curtice, K. Thomson, L. Jarvis and C. Bromley (eds), British Social Attitudes: The 19th Report (London: Sage), 141-167. 
Dalton, R. (2006) Citizen Politics: Public Opinion and Political Parties in Advanced Industrial Democracies (Washington: CQ Press).

Dalton, R. (2004) Democratic Challenges, Democratic Choices: The Erosion of Political Support in Advanced Industrial Democracies (New York: Oxford University Press).

Dalton, R. and Weldon, S. (2005) 'Public images of political parties: A necessary evil?', West European Politics, 28:5, 931-51.

Dasgupta, P. (1988) 'Trust as a commodity', in D. Gambetta (ed), Trust: Making and Breaking Cooperative Relations (Oxford: Basil Blackwell), 49-71.

Dirks, K. and Skarlicki, D. (2004) 'Trust in leaders: Existing research and emerging issues', in R. Kramer and K. Cook (eds), Trust and Distrust in Organization: Dilemmas and Approaches (New York: Russell Sage), 21-40.

Duck, S. (1997) The Handbook of Personal Relationships: Theory, Research and Interventions (New York: Wiley and Sons).

Edelman. (2008) Trust Barometer 2008. Available online at: www.edelman.com (accessed 21 April 2008).

Elster, J. (1979) Ulysses and the Sirens: Studies in Rationality and Irrationality (Cambridge: Cambridge University Press).

Elster, J. (1998) 'Deliberation and constitution making', in J. Elster (ed), Deliberative Democracy (Cambridge: Cambridge University Press), 97-122.

Fung, A. (2004) Empowered Participation: Reinventing Urban Democracy (Princeton: Princeton University Press).

Galston, W. (1988) 'Liberal virtues', American Political Science Review, 82, 1277-90.

Gambetta, D. (1988) 'Can we trust trust?', in D. Gambetta (ed), Trust (Oxford: Basil Blackwell), 213-37.

Gibson, J. and Caldeira, G. (1995) 'The legitimacy of the Court of Justice in the European Union: Models of institutional support', American Political Science Review, 89:2, 356376. 
Grosskopf, A. and Mondak, J. (1998) ‘Do attitudes toward specific Supreme Court decisions matter? The impact of Webster and Texas $v$. Johnson on public confidence in the Supreme Court', Political Research Quarterly, 51:3, 633-654.

Habermas, J. (1987) Theory of Communicative Action, vol. 2, translated by Thomas McCarthy (Boston: Beacon Press).

Habermas, J. (1996) Between Facts and Norms: Contributions to a Discourse Theory of Law and Democracy (Cambridge, MA: MIT Press).

Habermas, J. (1985) 'Remarks on the theory of Communicative Action', in G. Seebass and R. Toumela (eds), Social Action (Amsterdam: D. Reidel), 235.

Habermas, J. (1984) Theory of Communicative Action, vol. 1, translated by Thomas McCarthy (Boston: Beacon Press).

Haque, M. (1998) 'Legitimation crisis: A challenge for public service in the next century', International Review of Administrative Sciences, 64:1, 13-26.

Hardin, R. (1993) 'The street-level epistemology of trust', Politics and Society, 21, 505-529.

Hardin, R. (1999) 'Do we want trust in government?', in M. Warren (ed.), Democracy and Trust (Cambridge: Cambridge University Press), 22-41.

Harris Interactive. (2007). 'Lack of trust in both FDA and pharmaceutical companies makes drug safety a concern for many'. Available online at: http://www.harrisinteractive.com/news/newsletters/healthnews/HI_HealthCare News_2007_v07_i06.pdf (accessed 7 January 2008).

Hart, V. (1978) Distrust and Democracy: Political Distrust in Britain and America (Cambridge: Cambridge University Press).

Held, V. (1968) 'On the Meaning of Trust', Ethics, 78:2, 156-59.

Hertzberg, L. (1988) 'On the attitude of trust', Inquiry, 31:3, 307-22.

Hetherington, M. (2005) Why Trust Matters: Declining Political Trust and the Demise of American Liberalism (Princeton: Princeton University Press).

Hetherington, M. (1998) 'The political relevance of political trust', American Political Science Review, 92:4, 791-808.

Hibbing, J. and Theiss-Morse, E. (1995) Congress as Public Enemy (New York: Cambridge University Press). 
Horsburgh, H.J.N. (1960) 'The ethics of trust', Philosophical Quarterly, 10, 343-54.

Hunold, C. and Young, I. (1996) 'Justice, Democracy, and Hazardous Siting', Political Studies, 46, 82-95.

Inglehart, R. and Welzel, C. (2005) Modernization, Cultural Change and Democracy: The Human Development Sequence (New York: Cambridge University Press).

Inglehart, R. (1999) 'Trust, well-being and democracy', in M. Warren (ed), Democracy $\mathcal{E}$ Trust (Cambridge: Cambridge University Press), 88-120.

Jones, K. (1996) 'Trust as an affective attitude', Ethics 107:1, 4-25.

Kerr, N., and Kaufman-Gilliland, C. (1994) ,Communication, commitment, and cooperation in social dilemmas', Journal of Personality and Social Psychology, 66, 513-529.

King, D. (1997) 'The polarization of American parties and mistrust of government', in J. Nye, P. Zelikow and D. King (eds), Why people don't trust government (Cambridge: Harvard University Press), 155-178.

Kohut, A. (1998) Deconstructing Distrust: How Americans View Government. (Pew Research Center for the People and the Press).

Kramer, R. and Tyler, T. (1995) Trust in Organizations (New York: Sage).

Kleinnijenhuis, J., van Hoof, A. and Oegema, D. (2006) 'Negative news and the sleeper effect of distrust', Press/Politics, 11:2, 86-104.

Kumlin, S. (2002) 'Institutions - experiences - preferences: How welfare state design affects political trust and ideology', in B. Rothstein and S Steinmo (eds), Restructuring the Welfare State: Political Institutions and Policy Change (New York: Palgrave/Macmillan) 20-50.

Ladd, E. (1999) The Ladd Report (New York: Free Press).

Larmore, C. (1994) 'Pluralism and reasonable disagreement', in C. Larmore (ed), Morals of Modernity (Cambridge: Cambridge University Press), 28-30.

Levi, M. and Stoker, L. (2000) 'Political trust and trustworthiness', Annual Review of Political Science (3): 475-507.

Levi, M. (1997) Consent, Dissent, and Patriotism (Cambridge: Cambridge University Press).

Lieberman, E. (2003) Race and Regionalism in the Politics of Taxation in Brazil and South Africa (New York: Cambridge University Press). 
Lin, N. (2001) Social Capital: A Theory of Social Structures and Action (Cambridge: Cambridge University Press).

Macedo, S. (2005) Democracy at Risk: How Political Choices Undermine Citizen Participation and What We Can Do About It (Washington, D.C.: Brookings Institution Press).

Mackenzie, G. and Labiner, J. (2002) 'Opportunity lost: The rise and fall of trust in government after September 11', American Journal of Political Science, 48:1, 93-112.

Mansbridge, J. (1999) 'Altruistic trust', in M. Warren (ed), Democracy and Trust (Cambridge: Cambridge University Press), 290-309.

Mansbridge, J. (1983) Beyond Adversary Democracy (Chicago: University of Chicago Press).

McAllister, I. (1995) 'Affect and cognition-based trust as foundations for interpersonal cooperation in organizations', Academy of Management Journal, 38, 24-59.

McDonald, M. and Popkin, S. (2001) 'The myth of the vanishing voter', American Political Science Review, 95:4, 963-974.

Mendelberg, T. 2002. 'Political Decision Making', Deliberation and Participation, 6, 151-193.

Miller, A. (1974) 'Political issues and trust in government, 1964-1970', American Political Science Review, 68:4, 951-972.

Miller, A. and Borrelli, S. (1991) 'Confidence in government during the 1980s', American Politics Quarterly, 19, 147-173.

Mishler, W. and Rose, R. (2001) 'What are the origins of political trust: Testing institutional and cultural theories in post-Communist societies', Comparative Political Science, 34: $1,30-62$.

Newton, K. and Norris, P. (2000) 'Confidence in public institutions: Faith, culture, or performance?', in S. Pharr and R. Putnam (eds), Disaffected Democracies: What's Troubling the Trilateral Countries? (Princeton: Princeton University Press), 52-73.

Newton, K. (1999) 'Social and political trust in established democracies', in P. Norris (ed.), Critical Citizens: Global Support for Democratic Governance (Oxford: Oxford University Press), 169-187.

Newton, Kenneth. 2002. Who Trusts? The Origins of Social Trust in Six European Nations. Southampton: Department of Political Science, University of Southampton. 
Norris, P. (1999) Critical Citizens: Global Support for Democratic Governance (Oxford: Oxford University Press).

Nye, J., Zelikow, P. and King, D. (1997) Why People Don't Trust Government (Cambridge: Harvard University Press).

Orbell, J. M., van de Kragt, A. J. C., \& Dawes, R. M. (1988). Explaining Discussion-Induced Cooperation. Journal of Personality and Social Psychology, 54, 811-819.

Orren, G. (1997) 'Fall from grace: The public's loss of faith in government', in J. Nye, P. Zelikow, and D. King (eds), Why People Don't Trust Government (Cambridge: Harvard University Press), 77-108.

Ostrom, E. (1998) 'A behavioral approach to the Rational Choice theory of collective action' American Political Science Review, 92:1, 1-23.

Owen, D. and Dennis, J. (2001) 'Trust in federal government: The phenomenon and its antecedents', in J. Hibbing and E. Theiss-Morse (eds), What is it About Government that Americans Dislike? (New York: Cambridge University Press), 209-226.

Parker, S. and Parker, G. (1993) 'Why do we trust our congressman?', Journal of Politics, $55: 2,442-453$.

Patterson, S., Ripley, R. and Quinlan, S. (1992) 'Citizens' orientations towards legislatures: Congress and the state legislature', Western Political Quarterly, 45, 315-338.

Pattie, C. and Johnston, R. (2001) 'Losing the voters' trust: Evaluations of the political system and voting at the 1997 British general election', British Journal of Politics and International Relations, 3:2, 191-222.

Pattie, C., Seyd, P. and Whiteley, P. (2004) Citizenship in Britain (Cambridge: Cambridge University Press).

Pharr, S. and Putnam, R. (2000) Disaffected Democracies: What's Troubling the Trilateral Countries? (Princeton: Princeton University Press).

Rothstein, B. (2000) 'Trust, social dilemmas and collective memories', Journal of Theoretical Politics, 12:4, 477-503.

Rothstein, B. and Steinmo, S. (2002) 'Restructuring politics: Institutional analysis and the challenges of modern welfare states', in B. Rothstein and S. Steinmo (eds), Restructuring the Welfare State: Political Institutions and Policy Change (New York: Palgrave/Macmillan), 1-19. 
Sally, D. (1995) 'Conversation and cooperation in social dilemmas: A meta-analysis of experiments from 1958 to 1992', Rationality and Society, 7:1, 58-92.

Scholz, J. and Lubell, M. (1998) 'Adaptive political attitudes: Duty, trust and fear as monitors of tax policy', American Journal of Political Science, 42:3, 903-20.

Seligman, A. (1997) The Problem of Trust (Princeton: Princeton University Press).

Skocpol, T. (2003) Diminished Democracy: From Membership to Management in American Civic Life (Norman: University of Oklahoma Press).

Stokes, D. (1962) 'Popular evaluations of government: An empirical assessment', in H. Cleveland and H. Laswell (eds), Ethics and Business: Scientific, Academic, Religious, Political and Military (New York: Harper and Brothers), 61-72

Svallfors, S. (1997) 'Worlds of welfare and attitudes to redistribution: A comparison of eight Western nations', European Sociological Review, 13:3, 283-304.

Sztompka, P. (1999) Trust: A Sociological Theory. Cambridge: Cambridge University Press.

Tilly, C. (2005) Trust and Rule (New York: Cambridge University Press).

Torpe, L. (2000) Democratic Community as Social Capital (Aarlborg: Department of Economics, Politics and Public Administration).

Tucker, A. (2008) 'Trade associations as industry reputation agents: A theory of reputational trust', Business and Politics, 10:1, 4 .

Tucker, A. (2006) Reflexive Mistrust: Democratic Engagement in Deliberative Democracies (Georgetown University, Unpublished PhD Dissertation).

Tucker, A. (2004) 'The role of reflexive trust in modernizing public administrations' Public Performance and Management Review, 28:1, 53-74.

Tyler, T and Huo, Y. (2002) Trust in the Law: Encouraging Public Cooperation with the Police and Courts (New York: Russell Sage Foundation).

Uslaner, E. (2002) The Moral Foundations of Trust (Cambridge: Cambridge University Press).

Uslaner, E. (1999) Democracy and Social Capital, in M. Warren (ed), Democracy \& Trust (Cambridge: Cambridge University Press), 121-150

Verba, S., Schlozman, K. and Brady, H. (1995) Voice and Equality: Civic Voluntarism in American Politics (Cambridge: Harvard University Press). 
Warren, M. (1999) 'Democratic theory and trust', in M. Warren (ed), Democracy and trust (Cambridge: Cambridge University Press), 310-45.

Wright, J. (1976) The Dissent of the Governed: Alienation and Democracy in America (New York: Academic Press).

Yigoda, E. and Yuval, F. (2003) 'Managerial quality, administrative performance and trust in governance: Can we point to causality?', Australian Journal of Public Administration, 62:3, 12-25.

Young, I. (1999) 'Justice, inclusion and deliberative democracy', in S. Macedo (ed), Deliberative Politics: Essays on Democracy and Disagreement (New York: Oxford University Press), 151-8.

Zukin, C., Keeter, S., Andolina, M., Jenkins, K. and Delli Carpini, M. (2006) A New Engagement? Political Participation, Civic Life, and the Changing American Citizen (New York: Oxford University Press). 
Table 1. Responses to Questions on Trust 2007

\begin{tabular}{|c|c|c|c|c|c|}
\hline Trust Form & Institution & Question & $\begin{array}{r}\text { Strongly/ } \\
\text { Tend to } \\
\text { Agree (\%) }\end{array}$ & $\begin{array}{r}\text { Strongly/ } \\
\text { Tend to } \\
\text { Disagree } \\
(\%)\end{array}$ & $\begin{array}{r}\text { Net } \\
\text { Score }\end{array}$ \\
\hline \multirow[t]{5}{*}{ Strategic } & Parties & $\begin{array}{l}\text { (1) I can usually find a political party to vote } \\
\text { for that reflects at least some of my views }\end{array}$ & 62 & 20 & +42 \\
\hline & & $\begin{array}{l}\text { (2) The political party that wins an election } \\
\text { will usually reflect at least some of my views }\end{array}$ & 37 & 29 & +8 \\
\hline & & $\begin{array}{l}\text { (3) When political parties win power, they } \\
\text { generally do what they say they would }\end{array}$ & 16 & 64 & -48 \\
\hline & Politicians & $\begin{array}{l}\text { (4) The issues that politicians consider reflect } \\
\text { at least some of my concerns }\end{array}$ & 53 & 23 & +30 \\
\hline & & $\begin{array}{l}\text { (5) On balance, politicians deliver on their } \\
\text { promises }\end{array}$ & 12 & 66 & -54 \\
\hline \multirow[t]{3}{*}{ Moral } & Parties & $\begin{array}{l}\text { (6) Political parties that stand for election } \\
\text { bring together different types of people to } \\
\text { achieve common goals }\end{array}$ & 37 & 31 & +6 \\
\hline & & $\begin{array}{l}\text { (7) People involved in political parties are } \\
\text { people just like me }\end{array}$ & 19 & 64 & -45 \\
\hline & Politicians & $\begin{array}{l}\text { (8) Politicians share the same goals and values } \\
\text { as me }\end{array}$ & 12 & 61 & -49 \\
\hline \multirow[t]{5}{*}{ Deliberative } & Parties & $\begin{array}{l}\text { (9) Political parties try and represent their } \\
\text { supporters not just those who fund them }\end{array}$ & 24 & 47 & -23 \\
\hline & & $\begin{array}{l}\text { (10) It is more important to me that British } \\
\text { elections are properly democratic than which } \\
\text { party wins power }\end{array}$ & 64 & 15 & +49 \\
\hline & Politicians & $\begin{array}{l}\text { (11) It doesn't matter if I agree with the } \\
\text { outcome, so long as politicians have a full } \\
\text { opportunity to discuss an issue }\end{array}$ & 35 & 30 & +5 \\
\hline & & $\begin{array}{l}\text { (12) For the most part, politicians discuss the } \\
\text { issues that are most important to Britain }\end{array}$ & 34 & 39 & -5 \\
\hline & & $\begin{array}{l}\text { (13) One of the reasons why it is important to } \\
\text { have politicians is that we need people who are } \\
\text { able to consider and debate the many and } \\
\text { complex issues that face us }\end{array}$ & 64 & 15 & +49 \\
\hline
\end{tabular}


Table 2. Responses to Questions on Trust 2009

\begin{tabular}{|c|c|c|c|c|c|}
\hline Trust Form & Institution & Question & $\begin{array}{r}\text { Strongly/ } \\
\text { Tend to } \\
\text { Agree (\%) }\end{array}$ & $\begin{array}{r}\text { Strongly/ } \\
\text { Tend to } \\
\text { Disagree } \\
(\%)\end{array}$ & $\begin{array}{r}\text { Net } \\
\text { Score }\end{array}$ \\
\hline \multirow[t]{5}{*}{ Strategic } & Parties & & & & \\
\hline & & $\begin{array}{l}\text { (1) I can usually find a political party to vote } \\
\text { for that reflects at least some of my views }\end{array}$ & 72 & 11 & +61 \\
\hline & & $\begin{array}{l}\text { (2) The political party that wins an election } \\
\text { will usually reflect at least some of my views }\end{array}$ & 42 & 18 & +24 \\
\hline & Politicians & $\begin{array}{l}\text { (3) When political parties win power, they } \\
\text { generally do what they say they would } \\
\text { (4)The issues that politicians consider reflect } \\
\text { at least some of my concerns }\end{array}$ & 14 & 61 & -47 \\
\hline & & $\begin{array}{l}\text { (5) On balance, politicians deliver on their } \\
\text { promises }\end{array}$ & 60 & 15 & +45 \\
\hline \multirow[t]{3}{*}{ Moral } & Parties & $\begin{array}{l}\text { (6) Political parties that stand for election } \\
\text { bring together different types of people to } \\
\text { achieve common goals }\end{array}$ & & & \\
\hline & & $\begin{array}{l}\text { (7) People involved in political parties are } \\
\text { people just like me }\end{array}$ & 39 & 25 & +14 \\
\hline & Politicians & $\begin{array}{l}\text { (8) Politicians share the same goals and values } \\
\text { as me }\end{array}$ & 15 & 55 & -40 \\
\hline \multirow[t]{5}{*}{ Deliberative } & Parties & $\begin{array}{l}\text { (9) Political parties try and represent their } \\
\text { supporters not just those who fund them }\end{array}$ & 31 & 39 & -8 \\
\hline & & $\begin{array}{l}\text { (10) It is more important to me that British } \\
\text { elections are properly democratic than which } \\
\text { party wins power }\end{array}$ & 66 & 14 & +52 \\
\hline & Politicians & $\begin{array}{l}\text { (11) It doesn't matter if I agree with the } \\
\text { outcome, so long as politicians have a full } \\
\text { opportunity to discuss an issue }\end{array}$ & 38 & 31 & +7 \\
\hline & & $\begin{array}{l}\text { (12) For the most part, politicians discuss the } \\
\text { issues that are most important to Britain }\end{array}$ & 46 & 28 & +18 \\
\hline & & $\begin{array}{l}\text { (13) One of the reasons why it is important to } \\
\text { have politicians is that we need people who are } \\
\text { able to consider and debate the many and } \\
\text { complex issues that face us }\end{array}$ & 63 & 13 & +50 \\
\hline
\end{tabular}


Table 3. Trust Judgements in Parties 2007 and 2009

\begin{tabular}{|c|c|c|c|c|c|}
\hline & Constant & 2.037 ** & $(.207)$ & $2.202 * *$ & $(.335)$ \\
\hline \multirow[t]{3}{*}{ Strategic } & Parties keep promises & $.649 * *$ & $(.059)$ & $.823 * *$ & $(.086)$ \\
\hline & Can find a party that reflects my views & $.269 * *$ & $(.053)$ & $.474^{* *}$ & $(.083)$ \\
\hline & Winning party will reflect some of my views & $.246 * *$ & $(.059)$ & $\mathrm{n} / \mathrm{s}$ & \\
\hline \multirow[t]{2}{*}{ Moral } & People in parties are just like me & $.180 * *$ & $(.049)$ & $.297 * *$ & $(.077)$ \\
\hline & Parties bring people together & $\mathrm{n} / \mathrm{s}$ & & $\mathrm{n} / \mathrm{s}$ & \\
\hline \multirow[t]{2}{*}{ Deliberative } & Parties represent supporters, not funders & $.363 * *$ & $(.059)$ & $.235^{* *}$ & $(.079)$ \\
\hline & $\begin{array}{l}\text { More important that elections are democratic } \\
\text { than who wins }\end{array}$ & $\mathrm{n} / \mathrm{s}$ & & $-.234 * *$ & $(.071)$ \\
\hline \multirow[t]{4}{*}{ Controls } & Class & $\mathrm{n} / \mathrm{s}$ & & $\mathrm{n} / \mathrm{s}$ & \\
\hline & Sex & $\mathrm{n} / \mathrm{s}$ & & $\mathrm{n} / \mathrm{s}$ & \\
\hline & Age & $\mathrm{n} / \mathrm{s}$ & & $\mathrm{n} / \mathrm{s}$ & \\
\hline & Age Squared & $\mathrm{n} / \mathrm{s}$ & & $\mathrm{n} / \mathrm{s}$ & \\
\hline $\begin{array}{l}\text { Adjusted } R^{2} \\
\text { n }\end{array}$ & & $\begin{array}{r}.373 \\
1436\end{array}$ & & $\begin{array}{r}.332 \\
679\end{array}$ & \\
\hline
\end{tabular}


Table 4. Trust Judgements in Politicians 2007 and 2009

\begin{tabular}{|c|c|c|c|c|c|}
\hline & & 2007 & & 200 & \\
\hline & & $\mathrm{b}$ & S.E & $b$ & S.E. \\
\hline & Constant & 1.823 ** & $(.198)$ & $2.004 * *$ & $(.290)$ \\
\hline Strategic & Politicians keep promises & $.904 * *$ & $(.064)$ & $.944^{* *}$ & $(.083)$ \\
\hline & Politicians reflect my concerns & $.154^{* *}$ & $(.060)$ & $\mathrm{n} / \mathrm{s}$ & \\
\hline Moral & Politicians share my goals & $.413 * *$ & $(.065)$ & $.686 * *$ & $(.080)$ \\
\hline Deliberative & Politicians discuss most import issues & $.218 * *$ & $(.059)$ & $\mathrm{n} / \mathrm{s}$ & \\
\hline & Politicians needed for complex issues & $\mathrm{n} / \mathrm{s}$ & & $\mathrm{n} / \mathrm{s}$ & \\
\hline & $\begin{array}{l}\text { Discussion process more important than } \\
\text { outcome }\end{array}$ & $\mathrm{n} / \mathrm{s}$ & & $\mathrm{n} / \mathrm{s}$ & \\
\hline Controls & Class & $\mathrm{n} / \mathrm{s}$ & & $\mathrm{n} / \mathrm{s}$ & \\
\hline & Sex & $\mathrm{n} / \mathrm{s}$ & & $\mathrm{n} / \mathrm{s}$ & \\
\hline & Age & $\mathrm{n} / \mathrm{s}$ & & $\mathrm{n} / \mathrm{s}$ & \\
\hline & Age Squared & $\mathrm{n} / \mathrm{s}$ & & $\mathrm{n} / \mathrm{s}$ & \\
\hline $\begin{array}{l}\text { Adjusted } \mathbf{R}^{2} \\
\mathrm{n}\end{array}$ & & $\begin{array}{r}.402 \\
1487\end{array}$ & & $\begin{array}{l}.378 \\
720\end{array}$ & \\
\hline
\end{tabular}


Table 5. Trust Judgements in Parties 2007 and 2009

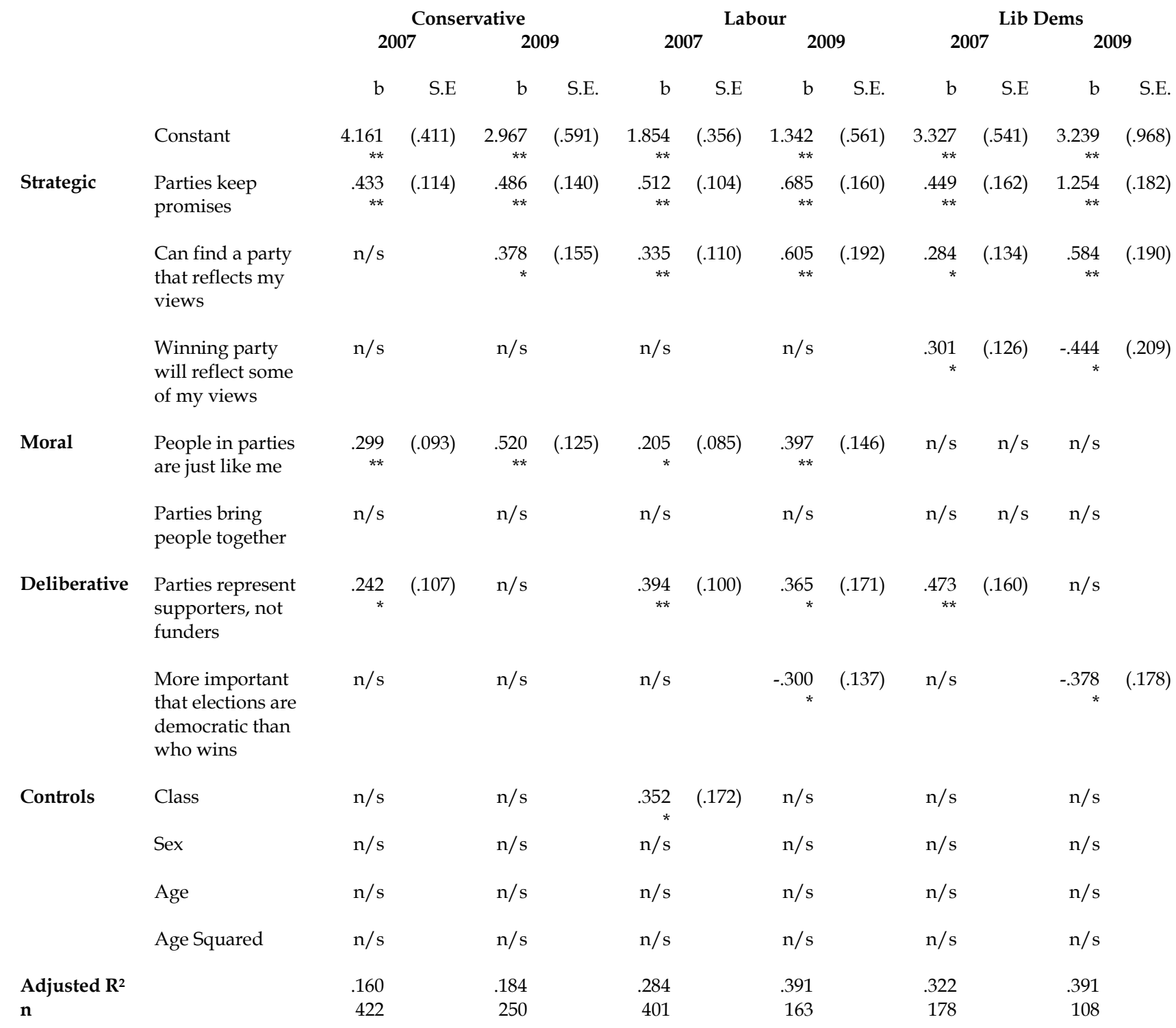


Table 6. Trust Judgements in Politicians 2007 and 2009

\begin{tabular}{|c|c|c|c|c|c|c|c|c|c|c|c|c|c|}
\hline & & \multicolumn{4}{|c|}{ Conservative } & \multicolumn{4}{|c|}{ Labour } & \multicolumn{4}{|c|}{ Lib Dems } \\
\hline & & \multicolumn{2}{|c|}{2007} & \multicolumn{2}{|c|}{2009} & \multicolumn{2}{|c|}{2007} & \multicolumn{2}{|c|}{2009} & \multicolumn{2}{|c|}{2007} & \multicolumn{2}{|c|}{2009} \\
\hline & & $\mathrm{b}$ & S.E & $b$ & S.E. & $b$ & S.E & $b$ & S.E. & $b$ & S.E & $b$ & S.E. \\
\hline & Constant & $\begin{array}{r}3.948 \\
* *\end{array}$ & $(.449)$ & $\begin{array}{r}3.267 \\
* *\end{array}$ & $(.591)$ & $\begin{array}{r}1.491 \\
* *\end{array}$ & $(.322)$ & $\begin{array}{r}1.168 \\
*\end{array}$ & $(.465)$ & $\begin{array}{r}4.087 \\
* *\end{array}$ & $(.556)$ & $\begin{array}{r}1.709 \\
*\end{array}$ & $(.790)$ \\
\hline \multirow[t]{2}{*}{ Strategic } & $\begin{array}{l}\text { Politicians keep } \\
\text { promises }\end{array}$ & $\begin{array}{r}.755 \\
* *\end{array}$ & $(.129)$ & $\begin{array}{r}1.009 \\
* *\end{array}$ & $(.156)$ & $\begin{array}{r}.777 \\
* *\end{array}$ & $(.101)$ & $\begin{array}{r}.896 \\
* *\end{array}$ & $(.156)$ & $\begin{array}{r}.865 \\
* *\end{array}$ & $(.143)$ & $\begin{array}{r}.733 \\
* *\end{array}$ & (.193) \\
\hline & $\begin{array}{l}\text { Politicians reflect } \\
\text { my concerns }\end{array}$ & $\mathrm{n} / \mathrm{s}$ & & $\mathrm{n} / \mathrm{s}$ & & $\mathrm{n} / \mathrm{s}$ & & $\mathrm{n} / \mathrm{s}$ & & $\mathrm{n} / \mathrm{s}$ & & $\mathrm{n} / \mathrm{s}$ & \\
\hline Moral & $\begin{array}{l}\text { Politicians share } \\
\text { my goals }\end{array}$ & $\begin{array}{r}.380 \\
* *\end{array}$ & $(.112)$ & $\mathrm{n} / \mathrm{s}$ & & $\begin{array}{r}.301 \\
* *\end{array}$ & $(.106)$ & $\begin{array}{r}.575 \\
* *\end{array}$ & $(.154)$ & $\mathrm{n} / \mathrm{s}$ & & $\begin{array}{r}.851 \\
* *\end{array}$ & $(.175)$ \\
\hline \multirow[t]{3}{*}{ Deliberative } & $\begin{array}{l}\text { Politicians discuss } \\
\text { most import } \\
\text { issues }\end{array}$ & $\mathrm{n} / \mathrm{s}$ & & $\begin{array}{r}.277 \\
*\end{array}$ & $(.123)$ & $\begin{array}{r}.449 \\
* *\end{array}$ & $(.102)$ & $\mathrm{n} / \mathrm{s}$ & & $\mathrm{n} / \mathrm{s}$ & & $\mathrm{n} / \mathrm{s}$ & \\
\hline & $\begin{array}{l}\text { Politicians needed } \\
\text { for complex } \\
\text { issues }\end{array}$ & $\mathrm{n} / \mathrm{s}$ & & $\mathrm{n} / \mathrm{s}$ & & $\mathrm{n} / \mathrm{s}$ & & $\begin{array}{r}.492 \\
* *\end{array}$ & $(.150)$ & $\begin{array}{r}.512 \\
* *\end{array}$ & $(.126)$ & $\mathrm{n} / \mathrm{s}$ & \\
\hline & $\begin{array}{l}\text { Discussion } \\
\text { process more } \\
\text { important than } \\
\text { outcome }\end{array}$ & $\mathrm{n} / \mathrm{s}$ & & $\mathrm{n} / \mathrm{s}$ & & $\mathrm{n} / \mathrm{s}$ & & $\mathrm{n} / \mathrm{s}$ & & $\mathrm{n} / \mathrm{s}$ & & $\mathrm{n} / \mathrm{s}$ & \\
\hline \multirow[t]{4}{*}{ Controls } & Class & $\begin{array}{r}-.605 \\
* *\end{array}$ & $(.186)$ & $\mathrm{n} / \mathrm{s}$ & & $\begin{array}{r}.392 \\
*\end{array}$ & $(.164)$ & $\mathrm{n} / \mathrm{s}$ & & $\mathrm{n} / \mathrm{s}$ & & $\begin{array}{r}.847 \\
*\end{array}$ & $(.389)$ \\
\hline & Sex & $\mathrm{n} / \mathrm{s}$ & & $\mathrm{n} / \mathrm{s}$ & & $\mathrm{n} / \mathrm{s}$ & & $\mathrm{n} / \mathrm{s}$ & & $\begin{array}{r}-.728 \\
* *\end{array}$ & $(.241)$ & $\mathrm{n} / \mathrm{s}$ & \\
\hline & Age & $\mathrm{n} / \mathrm{s}$ & & $\mathrm{n} / \mathrm{s}$ & & $\mathrm{n} / \mathrm{s}$ & & $\mathrm{n} / \mathrm{s}$ & & $\mathrm{n} / \mathrm{s}$ & & $\mathrm{n} / \mathrm{s}$ & \\
\hline & Age Squared & $\mathrm{n} / \mathrm{s}$ & & $\mathrm{n} / \mathrm{s}$ & & $\mathrm{n} / \mathrm{s}$ & & $\mathrm{n} / \mathrm{s}$ & & $\mathrm{n} / \mathrm{s}$ & & $\mathrm{n} / \mathrm{s}$ & \\
\hline $\begin{array}{l}\text { Adjusted } \mathbf{R}^{2} \\
\mathrm{n}\end{array}$ & & $\begin{array}{l}.223 \\
432\end{array}$ & & $\begin{array}{r}.201 \\
259\end{array}$ & & $\begin{array}{r}.364 \\
407\end{array}$ & & $\begin{array}{l}.469 \\
173\end{array}$ & & $\begin{array}{l}.294 \\
184\end{array}$ & & $\begin{array}{l}.408 \\
111\end{array}$ & \\
\hline
\end{tabular}




\section{Endnotes}

1 See for example, Dalton and Weldon, 2005, p. 935.

${ }^{2}$ For example, Burns and Kinder $(2000,4)$ criticise the National Election Studies question on trust: "We suspect that trust is domain-specific, but the measures of trust that dominate the empirical literature are based upon an entirely different assumption: namely, that people have in mind stable views about the trustworthiness of human nature in general."

${ }^{3}$ Of course, politicians often seek a wider audience for their views beyond those citizens with an interest in those views. In these cases, strategic trust is not relevant.

${ }^{4}$ This strand is not usually included in the political trust literature as it derives from deliberative democratic theory. As such, it has only recently been recognised by trust scholars (Tucker 2006).

5 The standard trust question from the British Election Study asks: "Now, thinking about British political institutions like Parliament, please use the 0 to 10 scale to indicate how much trust you have for each of the following, where 0 means no trust and 10 means a great deal of trust".

${ }^{6}$ There is some evidence, for example, that in the minds of electors, local politicians in much higher regard than political parties themselves (Bianco, 1994; Parker and Parker, 1993).

${ }^{7}$ Ideally, the impact of class would be measured by a series of dummy variables for each category minus one reference category. However, the data for the first survey were supplied in such a form that the existing dummy was the only one available. For comparability, we coded the 2009 data in the same way.

8 Pattie and Johnston $(2001,204-9)$ made a similar finding in respect of voters at the 1997 election. Those who voted Labour were more likely to trust parties and politicians. 